\title{
FRACTAL FEATURES OF SOIL TEXTURE AND PHYSICAL ATTRIBUTES IN INDIAN DARK EARTH UNDER DIFFERENT USES IN WESTERN AMAZON
}

\author{
CARACTERÍSTICAS FRACTAIS DA TEXTURA E ATRIBUTOS FÍSICOS DO SOLO \\ EM AREAS COM TERRA PRETA DE ÍNDIO SOB DIFERENTES USOS NA \\ AMAZONNIA OCIDENTAL
}

\author{
Half Weinberg Corrêa JORDÃ ${ }^{1}$; Milton César Costa CAMPOS $^{2}$; \\ José Maurício da CUNHA ${ }^{3}$; Ivanildo Amorim de OLIVEIRA ${ }^{4}$; Laércio Santos SILVA ${ }^{5}$; Elilson \\ Gomes de BRITO FILHO ${ }^{3}$; Bruno Campos MANTOVANELLI'; \\ Ludmila de FREITAS ${ }^{4}$; Romário Pimenta GOMES ${ }^{5}$ \\ 1. Universidade Estadual Paulista - UNESP, Departamento de Ciências Agrárias, Botucatu, SP, Brasil; 2. Universidade Federal da \\ Paraíba - UFPB, Departamento de Solos e Engenharia Rural, Areia, PB, Brasil. mcesarsolos@gmail.com; 3. Universidade Federal do \\ Amazonas - UFAM, Instituto de Educação, Agricultura e Ambiente, Humaitá, AM, Brasil; 4. Instituto Federal de Rondônia - IFRO, \\ Departamento de Agronomia, Ariquemes, RO, Brasil; 5. Universidade Estadual Paulista - UNESP, Departamento de Solos, Jaboticabal, \\ SP, Brasil; 6. Universidade Federal de Santa Maria - UFSM, Departamento de Solos, Santa Maria, RS, Brasil.
}

\begin{abstract}
Studying particle size distribution is important to understand soil structure and formation processes. This research aimed to assess the fractal dimension of soil texture in Indian Dark Earth (IDE) areas in southern Amazonas state under different land uses, as follows: two areas in the municipality of Apuí, one growing cocoa and the other coffee; a grassland area in the municipality of Manicoré; and a forest area in the municipality of Novo Aripuanã. A sampling grid containing 88 collection points (intersecting points on the grid) was established in each area, measuring $80 \times 42 \mathrm{~m}$ for the cocoa and coffee-growing sites, and $80 \times 56 \mathrm{~m}$ and $60 \times 42 \mathrm{~m}$ for the grassland and forest areas, respectively. Soil samples were collected in soil core and as clumps at a depth of $0.0-0.20 \mathrm{~m}$ to determine the structural physical properties and texture of the soil. The following physical attributes were assessed: texture (PSD), bulk density (BD), macroporosity (Macro), microporosity (Micro), total porosity (TP) and aggregate stability (GMD and WMD). The fractal dimension (D) of the soil texture was determined, followed by analysis of variance and comparison of the means using Tukey's test ( $\mathrm{p} \leq 0.05)$. Pearson's correlation was applied to assess the correlation between variables. There was a significant difference between the IDEs studied, with a higher D value in the cocoa-growing area in relation to the other sites. Additionally, the larger the clay fraction, the higher the $\mathrm{D}$ value. Fractal dimension (D) showed a positive correlation with sand, clay, BD, Macro, GMD and WMD, and a negative correlation with silt, micro, TP. Based on the D values obtained, the ADE cultivated with cocoa showed superior quality in relation to the other areas studied.
\end{abstract}

KEYWORDS: Fractal dimension. Soil physics. Soil use.

\section{INTRODUCTION}

Applications of fractal geometry in soil science have shown that soil exhibits fractal characteristics, being a porous medium having different particle compositions, with irregular shape and self-similar structure (TYLER; WHEATCRAFT, $1989 ; \quad$ KRAVCHENKO; ZHANG, 1998). Fractal geometry, proposed and established by Mandelbrot (1982), is a method for describing systems with non-characteristic scales and self-similarity. In recent years, this theory has been used to quantitatively describe the particle size distribution of soil, attracting the interest of pedologists worldwide (DENG et al., 2017). Particle size distribution is one of the most important physical characteristics of soil because of its significant influence on water flow and soil erosion (XU; LI; LI, 2013).

In this respect, broad and precise knowledge of particle size distribution is vital to understanding soil structures and formation, since it is closely related to soil erosion, organic matter content and moisture content (DU et al., 2017). Deng et al. (2017) studied the fractal features of soil particle size distribution and found an association between fractal dimensions and the physical and chemical properties of the soil analyzed, indicating that the lower the fractal dimension, the worse the soil physical and chemical properties. Recently, the fractal method was applied to estimate soil structure and proved to be an efficient tool in analyzing soil 
properties and their relationship with other environmental factors (XIA et al., 2015; DENG et al., 2017).

Textural analysis is commonly used to characterize particle size distribution (PSD) in soil, but the size definitions of the three main fractions (sand, silt and clay) are quite random and therefore cannot provide comprehensive information (DENG et al., 2017). In this case, according to the results of a study conducted by Xia et al. (2015), fractal dimension can be used to identify soil particle size characteristics. Additionally, Filgueira et al. (2006) reported that fractal theory and analysis can effectively describe soil texture.

According to Cunha et al. (2016), exhaustive soil use and management can irreparably damage its physical quality, thereby reducing its yield potential. In this context, a quantitative description of particle size distribution is important in soil structure research, and fractal dimension is a useful approach in quantitatively evaluating different land-use patterns (DENG et al., 2017).

In this research, verified the PSD and fractural dimensions of soils under different crops and natural environment, and identified the relationships between soil physical properties. The objective of this research was to evaluate the possibility that the fractal dimension of PSD can be used as an integrative index to quantify crop effects associated with structural quality in Indian Dark Earth in the Western Amazon.

\section{MATERIAL AND METHODS}

\section{Experiment location}

The soils were located in the region of the municipality of Apuí-AM, Brazil and Novo Aripuanã-AM, Brazil (Figure 1). The climate in the region was classified as humid tropical according to Köppen's classification, with a short dry period (between May and September), a mean annual temperature of 25 to $26^{\circ} \mathrm{C}$, rainfall from 2,200 to $2,700 \mathrm{~mm}$ and a relative air humidity of $85 \%$ to 90\% (BRASIL, 1978; CAMPOS et al., 2012). The characteristic vegetation of the region is tropical dense forest, consisting of dense multilayered trees between 15 and 20 meters high (ZEE, 2008).

The study was conducted at the four Indian Dark Earth (IDE) under different land uses. Two were located in the municipality of Apuí ( $7^{\circ} 12^{\prime} 05^{\prime}$ " $\mathrm{S}$ and $59^{\circ} 39^{\prime} 35^{\prime} \mathrm{W}$ ), one under cultivation for 14 years, growing rice, maize, beans and watermelon for six years and cocoa (Theobroma cacao) thereafter, and the other used a grassland for two years, followed by coffee (Coffea canephora) cultivation for four years. No machinery was used in either area to plant or maintain the crops. The soil in both IDEs areas was classified as Typic Hapludults, according to Soil Taxonomy (SOIL SURVEY STAFF, 2014) and "Argissolo Amarelo Eutrófico" to criteria established by the Brazilian Soil Classification System (SANTOS et al., 2018).
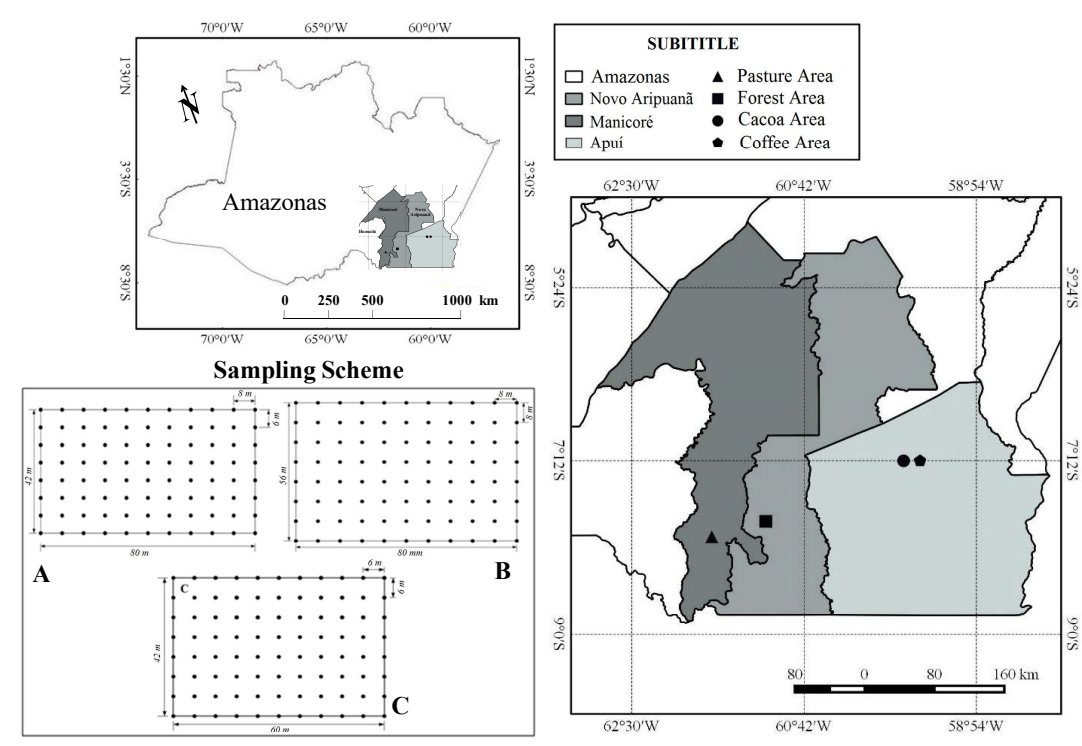

Figure 1. Location and representation of the sampling grid in the IDEs studied, with the respective spacing between collection points.

A - Cocoa and Coffee; B - Grassland; C - Forest.

The third area is located in the municipality of Manicoré (Figure 1) ( $7^{\circ} 59^{\prime} 22^{\prime \prime} \mathrm{S}$ and $61^{\circ} 39^{\prime}$
51.2" W, mean altitude of $83 \mathrm{~m}$ ), used for extensive grazing (Brachiaria brizantha) for approximately 7 
Fractal features...

years and capable of supporting livestock at around one unit/animal per hectare. The soil was classified as Typic Rhodudults (SOIL SURVEY STAFF, 2014) or "Argissolo Vermelho Amarelo Eutrófico" (SANTOS et al., 2018) and primary vegetation in the region is characterized as dense tropical forest. The final area (forest) was a forest fragment in the municipality of Novo Aripuanã (Figure 1) $\left(07^{\circ} 51^{\prime}\right.$ $30^{\prime \prime} \mathrm{S}$ and $61^{\circ} 18^{\prime} 01^{\prime \prime} \mathrm{W}$ ), preserved for more than 25 years and containing 15 to 20 -meter-high secondary trees, the soil types in this area classified as Xanthic Eutrudox (SOIL SURVEY STAFF, 2014) or "Latossolo Vermelho Amarelo latossólico" (SANTOS et al, 2018).

\section{Soil-sampling and evaluation of soil attributes}

A sampling grid was established in each area, with 88 collection points per grid. Grid dimensions were $80 \times 42 \mathrm{~m}$ in the cocoa and coffee areas, $80 \times 56 \mathrm{~m}$ in the grassland area and $60 \times 42 \mathrm{~m}$ in the forest area, with $6 \times 8 \mathrm{~m}$ spacing between points for the coffee and cocoa areas and $8 \times 8 \mathrm{~m}$ and $6 \times 6 \mathrm{~m}$ for the grassland and forest areas respectively (Figure 1).

In order to determine the structural and textural properties of the soil, deformed (clumps) and non-deformed samples were collected between $0.0-0.20 \mathrm{~m}$ depth, using a $4.0 \mathrm{~cm}$ high soil-core with an internal diameter of $5.1 \mathrm{~cm}$.

The following physical properties were determined to correlate fractal dimension with particle size: texture (sand, silt and clay), bulk density (BD), macroporosity (Macro), microporosity (Micro), total porosity (TP) and aggregate stability (GMD and WMD).

The particle size distribution (PSD) was determined with $1.0 \mathrm{~mol} \mathrm{~L}^{-1} \mathrm{NaOH}$ solution was used as chemical dispersant, with a resting time of 16 hours. Next, the suspension was transferred to steel cups containing water and coupled to an electric stirrer at 12,000 RPM for 15 minutes (TEIXEIRA et al., 2017). The clay fraction $(<0.002$ $\mathrm{mm}$ ) was separated using the pipette method, sand by sieving and silt $(0.05-0.002 \mathrm{~mm})$ was calculated based on the difference. The sand fraction was divided into coarse $(0.5-2.0 \mathrm{~mm})$, medium $(0.25-0.5$ $\mathrm{mm})$ and fine $(0.105-0.24 \mathrm{~mm})$ according to Arraes, Bueno and Pissarra (2010), in order to calculate the fractal dimension.

Next, the fractions obtained were sieved to determine the size of the solid particles analyzed, using a SOLOTEST sieve shaker with digital time and frequency adjustment to separate the particles through vibrations that accelerate sieving. Each sample was agitated for 3 minutes, using sieves with
JORDÃO, H. W. C. et al.

mesh sizes of $2 \mathrm{~mm} ; 1 \mathrm{~mm} ; 0.5 \mathrm{~mm} ; 0.250 \mathrm{~mm}$; $0.125 \mathrm{~mm}$ and $0.053 \mathrm{~mm}$.

The samples were prepared in the laboratory by removing the excess of soil from the soil core edges; they were then saturated by a gradual increase in water depth until reaching approximately $2 / 3$ of the soil core height. Total porosity was determined by the saturation method. Macroporosity was obtained from the balance of the set soil coresoil after applying --6 $\mathrm{kPa}$ in a tension table. In its turn, microporosity was obtained by subtracting the weight of the soil core-soil set equilibrated at $-6 \mathrm{kPa}$ and its respective oven-dried weight at $105{ }^{\circ} \mathrm{C}$.

Bulk density was determined by the soil core method as described in Grossman and Reinsch (2002). In this case, the soil in the soil core was oven dried at $105^{\circ} \mathrm{C}$ until constant weight.

Aggregate stability was assessed according to Kemper and Chepil (1965), with modifications in the following size classes:4.76-2.0 mm; 2.0-1.0 mm; $1.0-0.50 \mathrm{~mm} ; 0.50-0.25 \mathrm{~mm} ; 0.25-0.125 \mathrm{~mm} ; 0.125-$ $0.063 \mathrm{~mm}$. The aggregates were placed in contact with water in a $2.0 \mathrm{~mm}$ mesh sieve and submitted to vertical agitation in a Yoder sieve shaker (SOLOTEST) for $15 \mathrm{~min}$, at 32 oscillations per minute.

The material from each class retained in the sieve was dried in an oven at $105^{\circ} \mathrm{C}$ and the respective masses were measured on a digital balance. The weighted mean diameter (WMD) was calculated based on the formula proposed by Castro Filho, Muzilli and Podanoschi (1998) and the geometric mean diameter (GMD) in line with Schaller and Stockinger (1953) as cited by Alvarenga et al. (1986), using the following equations:

$W M D=\frac{\sum_{i=1}^{N} n_{i} D_{i}}{\sum n i}$ and $G M D=10^{\frac{\sum_{i=1}^{n} n_{i} \operatorname{lng} D_{i}}{\sum^{n} n i}}$

where:

$\mathrm{ni}=$ is the percentage of aggregates retained in the sieve, $\mathrm{Di}=$ the mean diameter of the sieve and $\mathrm{N}=$ the number of sieve classes.

Soil fractal model theory

The definition of a fractal can be given based on the relationship between number and size in a statistically self-similar system and defined by the following Equation 1 (MANDELBORT, 1982; TURCOTTE, 1986):

$N\left(X>x_{i}\right)=k x_{i}^{-D}$

In an effort to compensate for the lack of $\mathrm{N}$ values, Tyler and Wheatcraft (1989) estimated the 
fractal dimension of soil particle-size distribution, $\mathrm{Dm}$, based on the following Equation 2. Fractal dimension (D) was estimated using the particle size distribution (PSD) method proposed by Taylor and Wheatcraft (1992), based on the size distribution values for particles of coarse, medium and fine sand, silt and clay, according to the following equation:

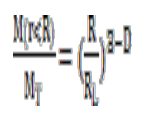

were:

$M=$ is the accumulated mass of the $r$-sized soil fractions (coarse, medium and fine sand, silt and clay) smaller than; $R=$ determined by the diameter of the sieves; $M_{T}=$ the total mass; $R_{L}=$ the parameter that estimates the largest particle size; $D$ $=$ the fractal dimension of the particles.

The equation is limited by the variation of $\mathrm{D}$, with $0<\mathrm{D}<3$, and is applied to describe the particle size distribution of dry soil.

\section{Statistical analysis}

The fractal dimension results obtained for each area were submitted to analysis of variance and, when significance was observed according to the F-test, the means were compared using Tukey's test at $5 \%$ probability. The correlation between fractal dimension and the physical attributes of the respective IDEs was analyzed using Pearson's correlation coefficient. All analyses were performed using Assistat software, version 7.7 (SILVA; AZEVEDO, 2016). D values were calculated using an electronic spreadsheet and R statistical software, version 3.4.1 (R CORE TEAM, 2013).

\section{RESULTS AND DISCUSSION}

\section{Soil particle-size distribution, fractal features and physical attributes}

As shown in Table 1, there are considerable differences in PSD among the four areas the IDEs in this study. The predominant soil particle size is sand, followed by silt. The average of the sand fraction range from $375.0 \mathrm{~g} / \mathrm{kg}^{-1}$ at $707.0 \mathrm{~g} / \mathrm{kg}^{-1}$, the clay content is relatively lower, range from 17.0 $\mathrm{g} / \mathrm{kg}^{-1}$ to $248.0 \mathrm{~g} / \mathrm{kg}^{-1}$ and the silt content between $199.0 \mathrm{~g} / \mathrm{kg}^{-1}$ at $607.0 \mathrm{~g} / \mathrm{kg}^{-1}$ (Table 1). Dominance of coarse particles in these areas of IDEs (forest and grassland) can be explained by the contribution of

\section{JORDÃO, H. W. C. et al.}

lithic and ceramic fragments, thus presenting higher levels for the sand fraction. Dominance of the sand and silt fraction was also reported by Campos et al. (2012); Mota Júnior et al. (2017) in anthropic soils in the city of Apuí-AM, associating this granulometric characteristic with the formation of these soils and constituent materials. In addition, it is important to note that the use of fire retardants in the presence of sand is more likely to occur in the sand (2000).

Considering IDEs under grassland and forest areas, the relationship of PSD has an influence on processes related to movement and retention of water, solute transport, heat and air in the soil. In the grassland area, due to the forces acting on the soil, the processes of degradation, decreased water retention capacity, soil nutrient loss and soil structure decrease are indicative of the selective removal of fine fractions and can be attributed to the anthropic processes and the source material acting in the formation of these soils. $\mathrm{Xu}$, Li and Li (2013) and Deng et al. (2017), observed similar behavior in non-anthropogenic soils as the granulometric fractions of sand. Cocoa and coffee areas presented domain of the silt fraction, in this case, the silt fraction together with clay, acted in the processes related to greater structuring and aggregation in these areas. 
Table 1. Descriptive statistics of the fractal dimension and physical attributes in Indian Dark Earth under different uses in the Western Amazon.

\begin{tabular}{|c|c|c|c|c|c|c|c|c|c|c|c|c|c|}
\hline Cocoa area & & & & & & & Coffee area & & & & & & \\
\hline Variable & Mean & StDev & CoefVar & Minimum & Maximum & $\mathbf{R}^{2}$ & Variable & Mean & StDev & CoefVar & Minimum & Maximum & $\mathbf{R}^{2}$ \\
\hline $\mathrm{D}$ & 2.80 & 0.02 & 0.79 & 2.76 & 2.85 & 0.851 & $\mathrm{D}$ & 2.43 & 0.02 & 0.79 & 2.39 & 2.54 & 0.822 \\
\hline Silt $\left(g / \mathrm{kg}^{-1}\right)$ & 549.89 & 21.00 & 3.82 & 491.13 & 590.56 & & Silt $\left(g / \mathrm{kg}^{-1}\right)$ & 607.96 & 26.64 & 4.38 & 531.20 & 666.06 & \\
\hline Clay (g/kg-1 $\left.{ }^{1}\right)$ & 248.03 & 39.27 & 15.83 & 174.09 & 341.12 & & Clay $\left(g / k g-{ }^{1}\right)$ & 17.29 & 2.94 & 16.99 & 13.09 & 38.74 & \\
\hline Sand $\left(g / \mathrm{kg}^{-1}\right)$ & 201.41 & 33.38 & 16.57 & 121.10 & 274.11 & & Sand $\left(g / \mathrm{kg}^{-1}\right)$ & 375.55 & 26.74 & 7.12 & 317.57 & 454.13 & \\
\hline $\mathrm{BD}\left(\mathrm{Mg} \mathrm{m}^{3}\right)$ & 0.93 & 0.09 & 9.22 & 0.59 & 1.15 & & $\mathrm{BD}\left(\mathrm{Mg} \mathrm{m}^{3}\right)$ & 1.14 & 0.14 & 12.63 & 0.72 & 1.43 & \\
\hline Macro $\left(\mathrm{cm}^{3} \mathrm{~cm}^{-3}\right)$ & 0.20 & 4.01 & 19.49 & 11.74 & 31.03 & & $\operatorname{Macro}\left(\mathrm{cm}^{3} \mathrm{~cm}^{-3}\right)$ & 0.19 & 3.94 & 20.49 & 9.54 & 27.52 & \\
\hline $\operatorname{Micro}\left(\mathrm{cm}^{3} \mathrm{~cm}^{-3}\right)$ & 0.46 & 3.26 & 7.03 & 35.64 & 53.49 & & Micro $\left(\mathrm{cm}^{3} \mathrm{~cm}^{-3}\right)$ & 0.38 & 1.99 & 5.21 & 34.25 & 45.09 & \\
\hline $\mathrm{TP}\left(\mathrm{cm}^{3} \mathrm{~cm}^{-3}\right)$ & 0.66 & 3.14 & 4.69 & 58.85 & 73.25 & & $\mathrm{TP}\left(\mathrm{cm}^{3} \mathrm{~cm}^{-3}\right)$ & 0.57 & 3.54 & 6.16 & 50.27 & 66.57 & \\
\hline GMD (mm) & 2.60 & 0.28 & 10.74 & 1.80 & 3.34 & & GMD (mm) & 2.55 & 0.28 & 10.86 & 1.73 & 3.19 & \\
\hline WMD (mm) & 2.87 & 0.21 & 7.24 & 2.19 & 3.35 & & WMD (mm) & 3.01 & 0.14 & 4.75 & 2.38 & 3.29 & \\
\hline Grassland area & & & & & & & Forest area & & & & & & \\
\hline $\mathrm{D}$ & 2.61 & 0.03 & 1.32 & 2.53 & 2.69 & 0.985 & $\mathrm{D}$ & 2.68 & 0.02 & 0.64 & 2.64 & 2.73 & 0.954 \\
\hline Silt $\left(g / \mathrm{kg}^{-1}\right)$ & 226.43 & 28.79 & 12.71 & 160.14 & 326.39 & & Silt $\left(g / \mathrm{kg}^{-1}\right)$ & 199.41 & 29.81 & 14.95 & 139.30 & 278.56 & \\
\hline Clay (g/kg-1 $\left.{ }^{1}\right)$ & 65.80 & 16.12 & 24.50 & 34.84 & 112.85 & & Clay $\left(g / k g-{ }^{1}\right)$ & 94.51 & 10.79 & 11.42 & 70.98 & 123.17 & \\
\hline Sand $\left(g / \mathrm{kg}{ }^{1}\right)$ & 707.76 & 28.63 & 4.05 & 606.14 & 759.59 & & Sand $\left(g / \mathrm{kg}^{-1}\right)$ & 705.69 & 30.88 & 4.38 & 627.90 & 767.96 & \\
\hline $\mathrm{BD}\left(\mathrm{Mg} \mathrm{m}^{3}\right)$ & 1.27 & 0.09 & 7.26 & 1.04 & 1.47 & & $\mathrm{BD}\left(\mathrm{Mg} \mathrm{m}^{3}\right)$ & 1.05 & 0.06 & 5.82 & 0.93 & 1.23 & \\
\hline $\operatorname{Macro}\left(\mathrm{cm}^{3} \mathrm{~cm}^{-3}\right)$ & 0.17 & 2.22 & 12.71 & 13.08 & 24.62 & & $\operatorname{Macro}\left(\mathrm{cm}^{3} \mathrm{~cm}^{-3}\right)$ & 0.18 & 2.00 & 10.74 & 13.02 & 23.46 & \\
\hline $\operatorname{Micro}\left(\mathrm{cm}^{3} \mathrm{~cm}^{-3}\right)$ & 0.38 & 2.31 & 6.06 & 27.30 & 45.09 & & Micro $\left(\mathrm{cm}^{3} \mathrm{~cm}^{-3}\right)$ & 0.22 & 1.69 & 7.41 & 19.50 & 26.40 & \\
\hline $\mathrm{TP}\left(\mathrm{cm}^{3} \mathrm{~cm}^{-3}\right)$ & 0.55 & 2.56 & 6.13 & 36.14 & 47.51 & & $\mathrm{TP}\left(\mathrm{cm}^{3} \mathrm{~cm}^{-3}\right)$ & 0.40 & 2.60 & 6.28 & 32.90 & 46.54 & \\
\hline GMD (mm) & 2.67 & 0.22 & 8.31 & 2.06 & 3.03 & & GMD (mm) & 2.03 & 0.31 & 15.09 & 1.42 & 2.73 & \\
\hline WMD (mm) & 3.10 & 0.10 & 3.19 & 2.82 & 3.25 & & WMD (mm) & 2.56 & 0.27 & 10.52 & 1.96 & 3.08 & \\
\hline
\end{tabular}

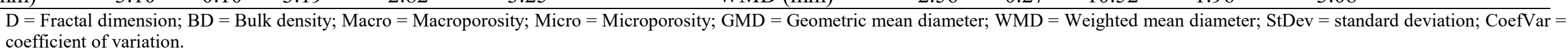


Fractal features...

The fractal dimension (D) values presented in Table 1 show differences between the IDEs under management and forest, in which they are characterized by a decrease in the fractal dimension, indicating that soils in the cultivated lands with cocoa are better, and coffee and grassland as highly influenced by management. This is because the sites with more expressive antropic spot were used for cultivation of species that provide greater input of vegetal residues. It is possible to verify that the greater the value of the clay fraction and the lower the $\mathrm{BD}$, the greater the $\mathrm{D}$, this corroborates with researches done by Liu et al. (2009) and Deng et al. (2017), in which they verified that the fractal dimension of the soil particle was larger when the texture was finer, corresponding to the particle size distribution of the soil. Overall, D values in the forest and cocoa area varied respectively from 2.68 to 2.80 . The variation of $\mathrm{D}$ values in all areas was relatively high, so the use of D based on PSDs could provide more information than just soil texture.

The coefficients of determination $\left(\mathrm{R}^{2}\right)$ showed, in general, values were satisfactory, that is, they can satisfactorily explain the results obtained for $\mathrm{D}$, since they ranged from 0.822 to 0.985 , indicating that on average $90 \%$ of the results obtained are explained by model. Huang et al. (2017) also found high $\mathrm{R}^{2}$ values, ranging from 0.961 to 0.992 , indicating that it is reasonable to use the fractal model to evaluate the particle size distribution of soils.

From the physical attributes of soil physical quality (macroporosity, microporosity, TP and BD), the degree of similarity between the different areas is evident, decreasing only to the forest area and grassland in attributes such as $\mathrm{TP}$ and $\mathrm{BD}$. In the condition of physical quality of soils, management areas and natural area, values higher than those established by the literature, mainly macroporosity, always higher than $15 \%$, as already highlighted in Tormena et al. (2002). In the forest area, physical variables of macro, micro and total porosity presented, respectively, $0.18,0.22$ and $0.4 \mathrm{~cm}^{3} \mathrm{~cm}^{-3}$ (Table 1), this behavior observed in forest area, leaves strong evidence of the low magnitude of the anthropic processes of formation of the IDEs at this site, thus considering low variation with areas where the anthropic formation process was more accentuated. Cocoa area presented significant results, in which the TP reached $0.66 \mathrm{~cm}^{3} \mathrm{~cm}^{-3}$, influencing a low $\mathrm{BD}$ of $0.93 \mathrm{Mg} \mathrm{m}^{3}$ (Table 1). Contrary to what was observed in the forest area, anthropic action was more expressive in this environment, even more associated with the great
JORDÃO, H. W. C. et al.

contribution of vegetal cover, which incorporates residues and lead to a greater formation of biopores by agents of the micro and meso fauna, favoring the diffusion of oxygen in the soil to the roots.

Effects of the influence of management on physical properties are more significant in the grassland area, mainly on the $\mathrm{BD}$, with values of 1.27 $\mathrm{Mg} \mathrm{m}^{3}$, making it evident that, anthropic soils are highly subject to degradation due to their management, and that the effects of the excess of animal grazzing can lead to the strong compaction of these soils, as it was evident the comparison with areas where the management is not very intense (cocoa and coffee) and mainly in natural area (forest).

Compared to the GMD values of the different systems of use in the IDEs (Table 1), there is reduced GMD in forest area with a value of 2.03 $\mathrm{mm}$, this behavior of aggregate diameter, disagrees with the characteristics of occurrence in soils of native conditions, making evident the influence of the sandy texture in the aggregate stabilization capacity. On the other hand, ADE under grassland presented higher GMD and WMD results, respectively $2.67 \mathrm{~mm}$ and $3.10 \mathrm{~mm}$. However, this behavior as highlighted by Mantovanelli et al. (2015) does not show in this specific case, better structural conditions, since these values of aggregates are due to the fact that the soil is at the level of compaction exerted by the animal grazzing and thus present greater resistance to rupture.

\section{Pearson correlation}

From Table 2 we present the Pearson correlation with emphasis on the correlation between $\mathrm{D}$ and other soil physical attributes. It is observed that the correlation coefficient was significant at $1 \%$ between $\mathrm{D}$ and the clay fraction, and significant at $5 \%$ probability between $\mathrm{D}$ and BD. D showed positive correlation with sand, clay, $\mathrm{BD}$, macro, GMD and WMD and negative correlation with silt, microporosity and $\mathrm{TP}$. 
Table 2. Pearson correlation of fractal dimension and physical attributes in Indian Dark Earth under different uses in the Western Amazon.

\begin{tabular}{|c|c|c|c|c|c|c|c|c|c|c|}
\hline & D & Sand & Silt & Clay & BD & Macro & Micro & TP & GMD & WMD \\
\hline D & 1 & 0,09 & $-0,08$ & $0,29^{* *}$ & $0,21^{*}$ & 0,06 & $-0,13$ & $-0,11$ & 0,20 & 0,13 \\
\hline Sand & & 1 & $-0,04$ & $0,27^{*}$ & $0,23^{*}$ & $-0,01$ & $-0,17$ & $-0,25^{*}$ & $-0,06$ & $-0,07$ \\
\hline Silt & & & 1 & 0,02 & $-0,03$ & $-0,08$ & 0,13 & 0,05 & 0,17 & $0,21^{*}$ \\
\hline Clay & & & & 1 & $0,21^{*}$ & $-0,11$ & $-0,08$ & $-0,10$ & $-0,02$ & $-0,06$ \\
\hline BD & & & & & 1 & $-0,52^{* *}$ & 0,08 & $-0,65^{* *}$ & $-0,08$ & $-0,14$ \\
\hline Macro & & & & & & 1 & $-0,46^{* *}$ & $0,71^{* *}$ & 0,12 & 0,18 \\
\hline Micro & & & & & & & 1 & 0,14 & 0,01 & 0,002 \\
\hline $\mathbf{T P}$ & & & & & & & & 1 & 0,14 & $0,23^{*}$ \\
\hline GMD & & & & & & & & & 1 & $0,72^{* *}$ \\
\hline WMD & & & & & & & & & & 1 \\
\hline
\end{tabular}

** Significant at $1 \%$ probability level; * Significant at the $5 \%$ probability level; $\mathrm{D}=$ fractal dimension; $\mathrm{BD}=$ Bulk density; Macro $=$ Macroporosity; Micro = Microporosity; $\mathrm{TP}=$ total porosity; $\mathrm{GMD}=$ Geometric mean diameter; $\mathrm{WMD}=$ Weighted mean diameter.

From the soil texture, high correlation of the clay fraction with $\mathrm{D}$ was observed, corroborating works by Xu, Li and Li (2013); Xia et al. (2015) and Deng et al. (2017), who found a positive and strong correlation of the clay fraction with D. However, in their respective studies, $\mathrm{Xu}, \mathrm{Li}$ and $\mathrm{Li}$ (2013) and Huang et al. (2017) found a strong positive correlation between $\mathrm{D}$ with silt fraction and negative correlation with sand fraction, differently from what was observed in this work, where silt presented negative correlation (-0.08) and sand positive correlation (0.09), thus not corroborating with the authors mentioned above. Huang et al. (2017) evaluated changes in texture, structure stability and nutrient availability of artificial soils on the slopes due to restoration time in Southeast China and found significant correlation coefficient between $\mathrm{D}$ and $\mathrm{BD}$, but this correlation was negative in order of 0.805 . These results, different from the present study, however should be considered that the authors worked in areas that underwent intensive soil structure management, which certainly influence $\mathrm{BD}$ values.

In a study by Liao et al. (2017), verified that the soil moisture showed a weak spatial dependence according to the fractal dimension criteria. Thus, it is stated that, in general, the fractal dimension is better than the ratio of nugget/range effect in describing the spatial dependence of soil properties.

In this context, the $\mathrm{D}$ of the soil particle size distribution, is an important tool to describe mainly attributes that characterize soil types, in addition, Deng et al. (2017) make an association of values of $\mathrm{D}$ with the quality of the physical-chemical properties of the soil, so the lower the value of $D$ the lower the quality of the soil.

\section{Relationship between fractal dimension and soil particle-size distribution}

Linear regression analyzes were performed to determine the relationships between $\mathrm{D}$ and the sand, silt and clay contents (Figures 2 and 3) in the different areas of IDEs. The statistical results obtained from the 88 sample points show that the fractal dimension of the PSD has a strong positive correlation with the clay content in all IDEs (Figure $2 \mathrm{~B}, \mathrm{n}=88, \mathrm{R}^{2}=0.99, \mathrm{P}<0.05$, Figure $2 \mathrm{E}, \mathrm{n}=88$, $\mathrm{R}^{2}=0.94, \mathrm{P}<0.05$, Figure $3 \mathrm{~A}, \mathrm{n}=88, \mathrm{R}^{2}=0.88, \mathrm{P}$ $<0.05$, Figure $3 \mathrm{E}, \mathrm{n}=88, \mathrm{R}^{2}=0.97, \mathrm{P}<0.05$ ). Results indicate a weak relationship between $\mathrm{D}$ and sand content in the different systems of IDEs use, except in the cocoa are $\left(R^{2}=0.71\right.$, Figure $\left.2 C\right)$, the negative correlation is evident in the other areas, with $\mathrm{R}^{2}$ ranging from 0.08 to 0.13 . Thus, regression analysis indicates that IDEs with higher clay contents and smaller sand fractions have higher D values. Other studies have shown similar results in very different landscapes and under contrasting climatic conditions (LIU et al., 2009).

From the linear regressions in the areas cultivated with cocoa (Figure 2 A-B-C) and forest area (Figure 3 A-B-C), it was verified that there was a significant decrease in the coefficient of determination between the different textural fractions, thus having a difference between the D of a natural and cultivated environment. A similar result was found by $\mathrm{Xu}, \mathrm{Li}$ and $\mathrm{Li}$ (2013), where they verified that the differences between cultivated areas and forest environments are characterized by a decrease in the fractal dimension, indicating that soils in agricultural lands are better. However, it is worth mentioning that the relationships between the cultivated areas with cocoa (Figure 2 A-B-C) and coffee (Figure 2 D-E-F) were too deferential, with the cultivated area with coffee, lower values in relation, thus evidencing that not only the environment, but also the type of crop cultivated can influence the D. Despite the fact that these two 
cultivated areas are close to each other and present the same soil class over the years, their management was different, since the cocoa area was previously cultivated by other crops (rice, corn, beans and watermelon), while the coffee area, besides having a few years of cultivation, in the first two years was used by grassland.

The characteristics of $\mathrm{D}$ verified from the linear regressions and the relationships with the PSD (Figures 2 and 3), thus indicate, accelerated the physical soil structuring process in the evolution of
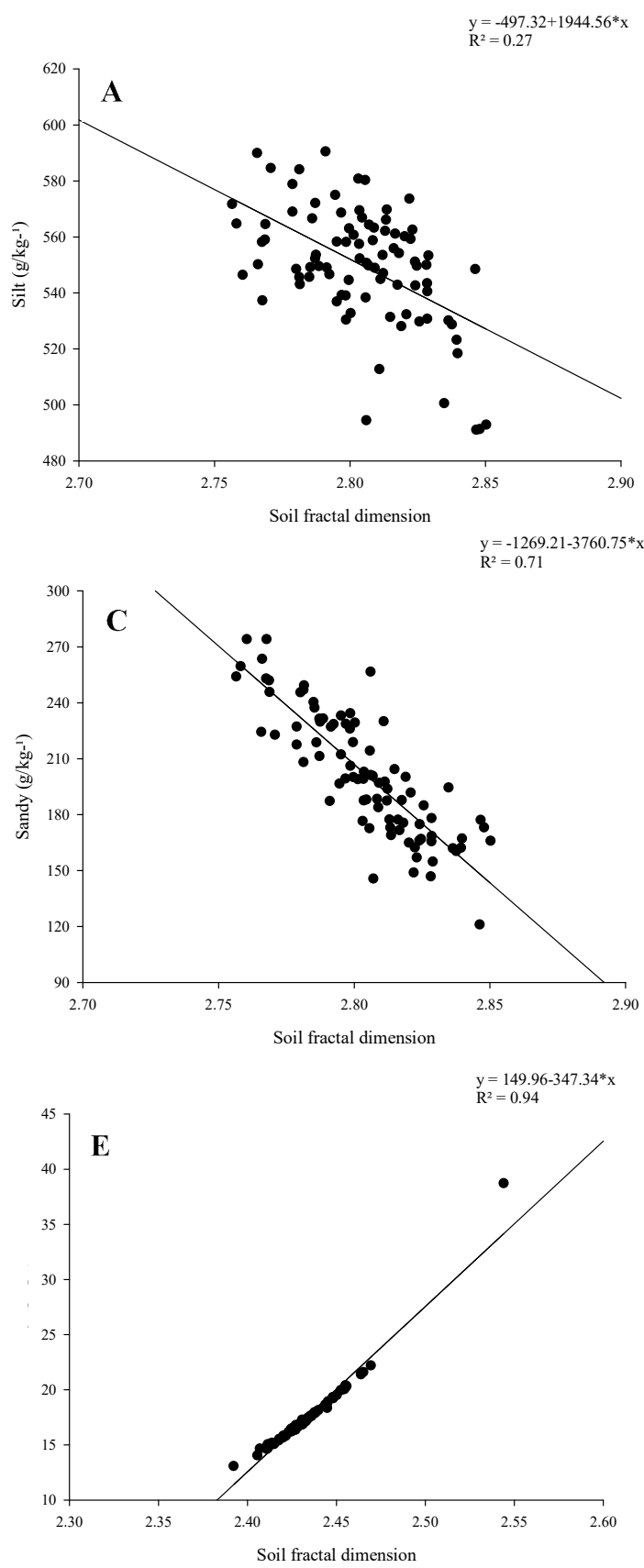

JORDÃO, H. W. C. et al.

the IDE formation process under cocoa cultivation. The effects associated to higher ratio of clay fraction in this crop, associated with the high organic matter input, lead to a maintenance of organic carbon and nutrients, mainly attributed to fine particles that enrich with stable organic $\mathrm{C}$ and $\mathrm{N}$, as well as increase of formation of particulate organic matter. As the proportion of coarse fractions increases, the negative correlation obtained is evident, thus evidencing the tendency of decrease in the levels of organic carbon.
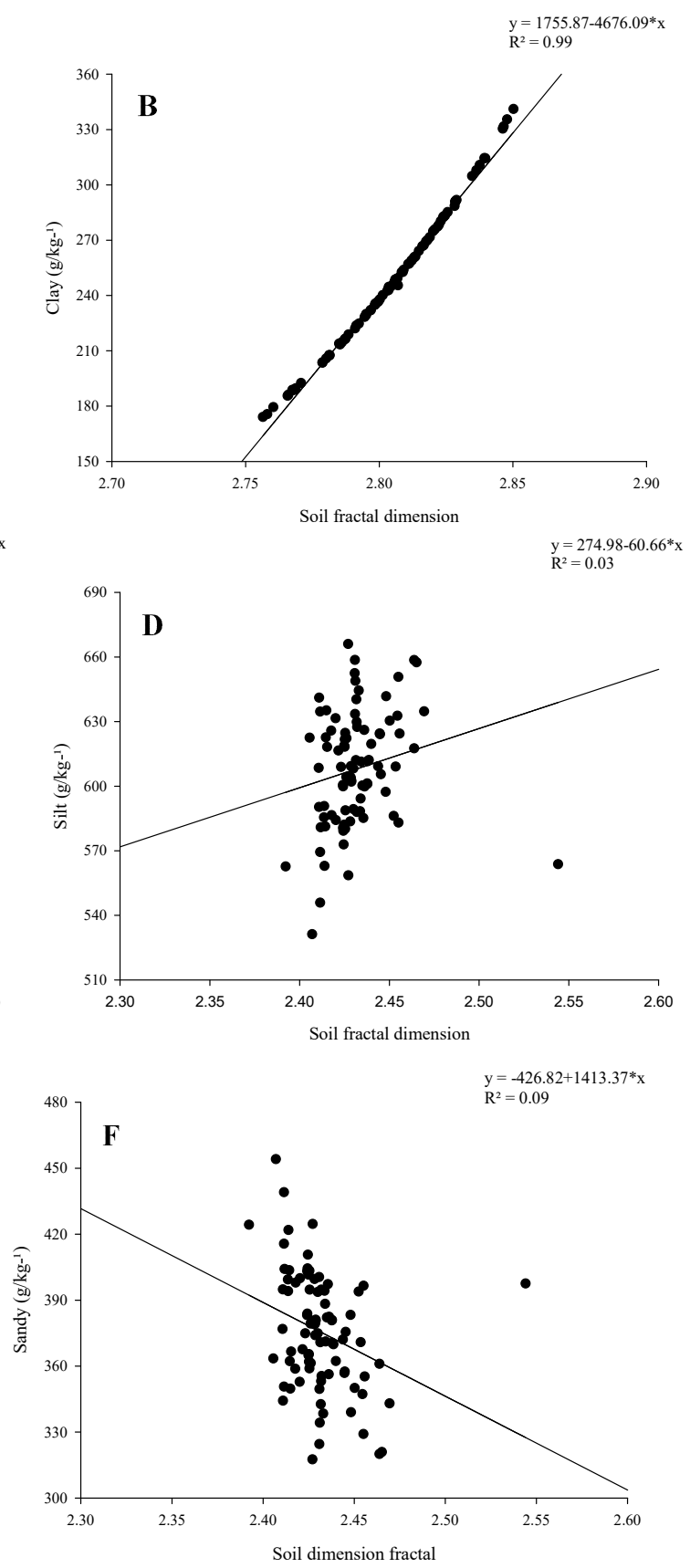

Figure 2. Relationship between fractal dimension and particle size distribution on Indian Dark Earth under different uses in the Western Amazon.

A-B-C: Cocoa area; D-E-F: Cooffe area. 
Fractal features...
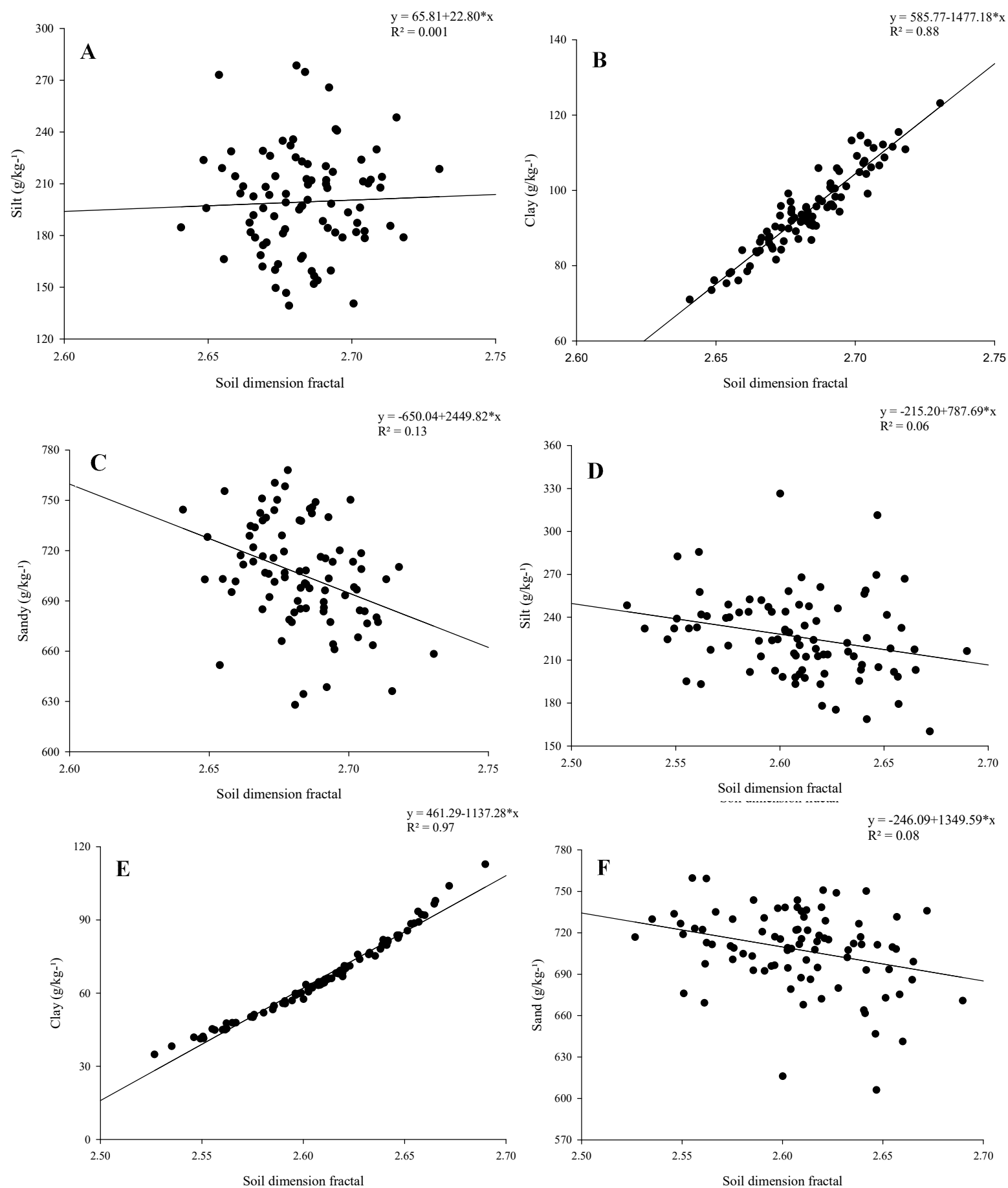

Figure 3. Relationship between fractal dimension and particle size distribution on Indian Dark Earth under different uses in the Western Amazon.

A-B-C: Forest area; D-E-F: Grassland area.

\section{Relationship between fractal dimension, GMD and WMD}

Linear regressions were also performed to determine the relationships between D and GMD and WMD aggregation variables for the different crops (Figure 4). In spite of the other physical attributes studied, the relationships with GMD and WMD were those that presented coherent relations with the values of $\mathrm{D}$, however these same values, are very low as to the determination index $\mathrm{R} 2$, in which area under cocoa cultivation presented $\left(\mathrm{R}^{2}=\right.$ 0.03 and 0.06 ), with a negative linear relationship (Figure 4 A-B). ADE under grassland presents constant relation, tending to a positive linear, however again the values of $\mathrm{R}^{2}$ are considered extremely low varying between 0.006 for GMD and 0.008 for WMD (Figure 4 C-D), however, as previously mentioned, this specific condition does 
not demonstrate expressive results of adequate aggregation conditions for this area, only possible compaction effects induce this condition.

IDEs areas, present high proportions of organic carbon, being verified this condition in studies of Soares et al. (2018) in grassland in southern Amazonas and also by Silva et al. (2017) that found high levels of native forest in the South of Amazonas. In particular, the increase in total organic carbon content generally results in an increase in the size and stability of the aggregates
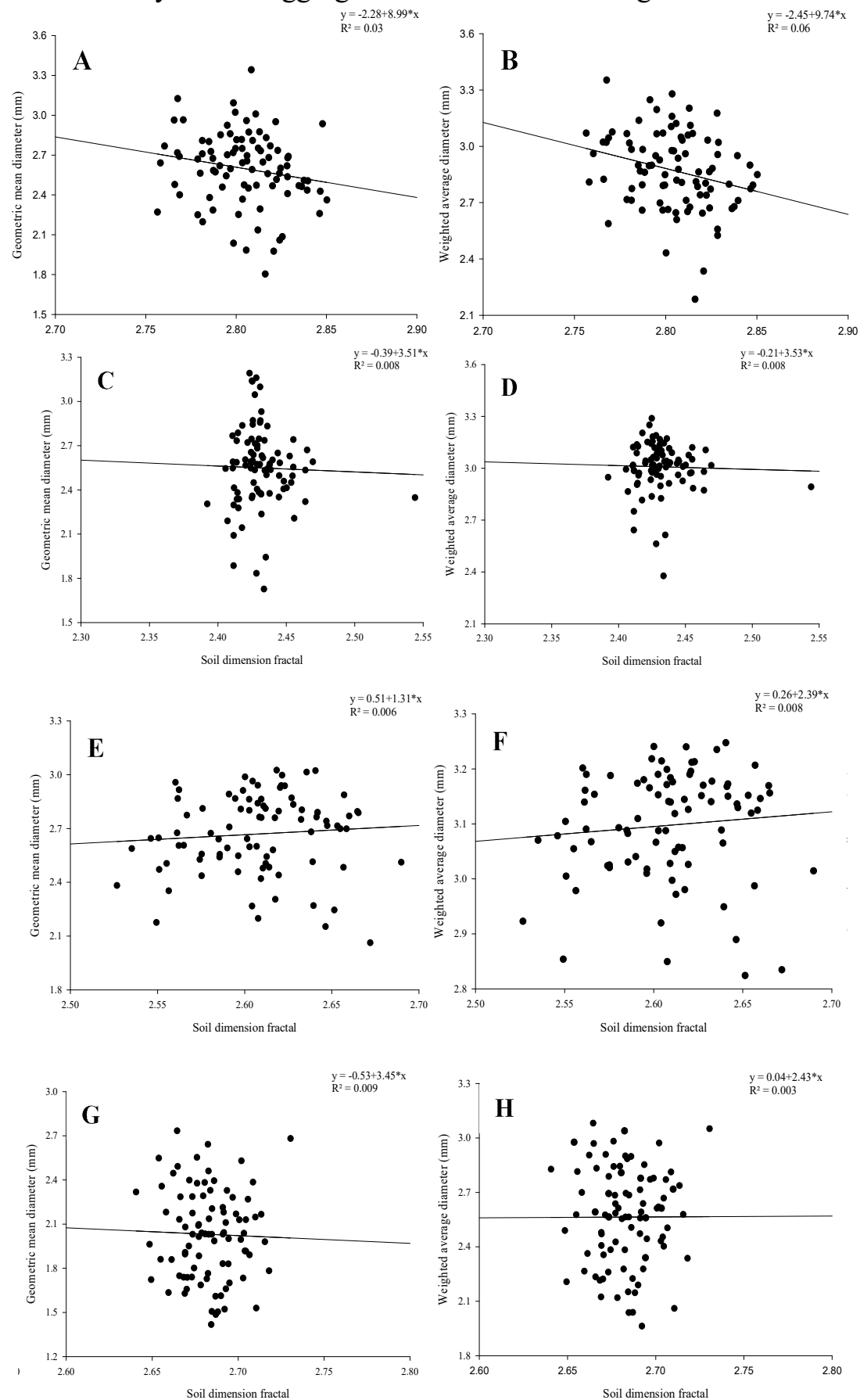

Figure 4. Relationship between fractal dimension, GMD and WMD in Indian Dark Earth under different uses in Western Amazonia.

A-B: Cocoa area; C-D: Cooffe area; E-F: Grassland area; G-H: Forest area. 
Fractal features...

There are recognized difficulties in relating the soil structure to the specific functions exerted by them in the processes of pedogenesis (GUBER; PACHEPSKY; LEVKOVSKY, 2005). Therefore, these difficulties are caused by the multiplicity of factors that affect the soil structure and multiplicity of effects that the structure has on the processes in the soil. Therefore, in spite of the complexity of the anthropic process of IDE formation, the aggregation scale requires parameterization that can better relate the effects with fractal dimension studies, since the textural variation associated with conditions of different diameters of aggregates presented low relations.

\section{CONCLUSIONS}

The mean fractal dimension values in the Indian Dark Earth studied here indicate better soil structure in the cocoa-growing area when compared to the other sites, possibly due to the land use and management of this environment. The clay fraction directly influenced fractal dimension values in the Indian Dark Earth areas.
JORDÃO, H. W. C. et al.

There were considerable linear relationships between the clay content in the different areas. It has been suggested that the fractal dimension of PSD may have significant implications for soil degradation or land-use structuring.

The search for informative parameters of the soil structure associating parameters of aggregation with fractal dimension, is the hope that the research in the aggregate scale can generate useful complements for the parameterization of the soil structure in Amazonian anthropic soils, evident the low relation found, thus showing the peculiar characteristic of these soils of the Amazon region.

\section{ACKNOWLEDGEMENTS}

This work was carried out with the support of the "Coordenação de Aperfeiçoamento de Nível Superior (CAPES)", "Conselho Nacional de Desenvolvimento Científico e Tecnológico, (CNPQ)", "Fundação de Amparo à Pesquisa do Estado do Amazonas (FAPEAM)" and "Universidade Federal do Amazonas (UFAM)".

RESUMO: Estudar a distribuição do tamanho das partículas é importante para entender a estrutura do solo e os processos de formação. Esta pesquisa teve como objetivo avaliar a dimensão fractal da textura do solo em áreas de Terra Preta de Índio (TPI) no sul do Estado do Amazonas sob diferentes usos da terra: duas áreas no município de Apuí, uma com cultivo de cacau e outra de café; uma área de pastagem no município de Manicoré; e uma área florestal no município de Novo Aripuanã. Uma malha de amostragem contendo 88 pontos de coleta (pontos de interseção na grade) foi estabelecida em cada área, medindo $80 \times 42 \mathrm{~m}$ para as áreas de cacau e café, e 80 × $56 \mathrm{~m}$ e 60 x $42 \mathrm{~m}$ para as áreas de pastagem e floresta, respectivamente. Amostras de solo foram coletadas em torrões a uma profundidade de 0,0-0,20 m para determinar as propriedades físicas estruturais e a textura do solo. Os seguintes atributos físicos foram avaliados: textura, densidade do solo (DS), macroporosidade (Macro), microporosidade (Micro), porosidade total (PT) e estabilidade de agregados (DMG e DMP). Determinou-se a dimensão fractal da textura do solo (D), seguida da análise de variância e comparação das médias pelo teste de Tukey $(\mathrm{p} \leq 0,05)$. A correlação de Pearson foi aplicada para avaliar a correlação entre as variáveis. Houve uma diferença significativa entre as TPIs estudadas, com um maior valor D na área de cultivo de cacau em relação aos outros locais. Além disso, quanto maior a fração argila, maior o valor de D. A dimensão fractal (D) apresentou correlação positiva com areia, argila, DS, Macro, DMG e DMP, e correlação negativa com silte, micro, PT. Com base nos valores de D obtidos, as TPIs cultivadas com cacau apresentaram qualidade superior em relação às demais áreas estudadas.

PALAVRAS-CHAVES: Dimensão Fractal. Física do solo. Uso do solo.

\section{REFERENCES}

ALVARENGA, R. C.; FERNANDES, B.; SILVA, T. C. A.; RESENDE, M. Estabilidade de agregados de um Latossolo Roxo sob diferentes métodos de preparo do solo e de manejo da palha do milho. Revista Brasileira de Ciência do Solo, Viçosa, v. 10, n. 2, p. 273-277, 1986. 
ARRAES, C. L.; BUENO, C. R. P.; PISSARRA, T. C. T. Estimativa da erodibilidade do solo para fins conservacionistas na microbacia córrego do Tijuco, SP. Bioscience Journal, Uberlândia, v. 26, n. 6, p. 849857, 2010. http://www.seer.ufu.br/index.php/biosciencejournal/article/view/7218/6604

BRASIL. Ministério das Minas e Energia. Projeto RADAMBRASIL, folha SB. 20, Purus. Rio de Janeiro, 1978.

CAMPOS, M. C. C.; SANTOS, L. A. C.; SILVA, D. M. P.; MANTOVANELLI, B. C.; SOARES, M. D. R. Caracterização física e química de terras pretas arqueológicas e de solos não antropogênicos na região de Manicoré, Amazonas. Revista Agro@mbiente Online, Boa Vista, v. 6, n. 2, p. 102-109, 2012. http://dx.doi.org/10.18227/1982-8470ragro.v12i4.5166

CASTRO FILHO, C.; MUZILLI, O.; PODANOSCHI, A. L. Estabilidade dos agregados e sua relação com o teor de carbono orgânico em um Latossolo Roxo Distrófico, em função de sistemas de plantio, rotações de culturas e métodos de preparo das amostras. Revista Brasileira de Ciência do Solo, Viçosa, v. 22, n. 23, p. 527-538, 1998. http://dx.doi.org/10.1590/S0100-06831998000300019

CHENU, C.; GUÉRIF, J. Mechanical strength of clay minerals as influenced by an adsorbed polysaccharide. Soil Science Society of America Journal, Madison, v. 55, n. 4, p. 1077-1080, 1992. http://doi.org/10.2136/sssaj1991.03615995005500040030x

CUNHA, J. M.; CAMPOS, M. C. C.; GAIO, D. C.; NOGUEIRA, J. S.; SOARES, M. D. R.; SILVA, D. M. P.; OLIVEIRA, I. A. Fractal analysis in the description of soil particle-size distribution under different land-use patterns in Southern Amazonas State, Brazil. African journal of agricultural research, Lagos, v. 11, n. 23, p. 2032-2042, 2016. http://doi.org/10.5897/AJAR2015.10649

DENG, Y.; CAI, C.; XIA, D.; DING, S.; CHEN, J. Fractal features of soil particle size distribution under different land-use patterns in the alluvial fans of collapsing gullies in the hilly granitic region of southern China. Plos One, San Francisco, v. 12, n. 3, p. 1-21, 2017. https://doi.org/10.1371/journal.pone.0173555

TEIXEIRA, P. C.; DONAGEMA, G. K.; FONTANA, A.; TEIXEIRA, W. G. Manual de métodos de análise de solo. Rio de Janeiro- RJ, Embrapa Solos, 2017, 574 p.

DU, Y. C.; HAN, J. C.; ZHANG, S. W.; HUANG, Y. F.; WANG, H. Y.; LUO, L. T.; ZHANG, W. H. Multidimensional analysis of particle size fractal characteristics in a farmland soil profile. IOP Conference Series Earth and Environmental Science, Bistrol, v. 52, n. 1, p. 1-10, 2017. http://doi.org/10.1088/1742$6596 / 52 / 1 / 012053$

SANTOS, H. G.; JACOMINE, P. K. T.; ANJOS, L. H. C.; OLIVEIRA, V. A.; LUMBRERAS, J. F.; COELHO, M. R.; ALMEIDA, J. A.; ARAUJO FILHO, J. C.; OLIVEIRA, J. B.; CUNHA, T. J. F. Sistema Brasileiro de Classificação de Solos. $5^{\text {a }}$ ed. Brasília, EMPRESA BRASILEIRA DE PESQUISA AGROPECUÁRIA Embrapa, 2018, 356 p.

FILGUEIRA, R. R.; FOURNIER, L. L.; CERISOLA, C. I.; GELATI, P.; GARCIA, M. G. Particle-size distribution in soils: A critical study of the fractal model validation. Geoderma, Amsterdã, v. 134, n. 3, p. $327-$ 334, 2006. https://doi.org/10.1016/j.geoderma.2006.03.008

GROSSMAN, R. B.; REINSCH, T. G. Bulk density and linear extensibility. In: DANE, J. H. \& TOPP, C., eds. Methods of soil analysis: Physical methods. Soil Science Society of America, p. 201-228, 2002. https://doi.org/10.2136/sssabookser5.4.c9

GUBER, A. K.; PACHEPSKY, Y. A.; LEVKOVSKY, E. V. Fractal mass-size scaling of wetting soil aggregates. Ecological Modelling, Estados Unidos, v. 182, n. 3-4, p. 317-322, 2005.

http://doi.org/10.1016/S0304-3800(04)00166-8 
HUANG, Z.; CHEN, J.; AI, X.; LI, R.; AI, Y.; LI, W. The texture, structure and nutrient availability of artificial soil on cut slopes restored with OSSS - Influence of restoration time. Journal of Environmental Management, Estados Unidos, v. 200, v. 200, n. 1, p. 502-510, 2017. http://doi.org/10.1016/j.jenvman.2017.05.043

KAY, B. D.; ANGERS, D. A. Soil structure. In: Sumner, M. E. (Ed.), Handbook of Soil Science. p. 229-276, 2000.

KEMPER, W. D.; CHEPIL, W. S. Size distribution of aggregates. In: Black, C. A.; Evans, D. D.; White, J. L.; Ensminger, L. E.; Clark, F. E. (Ed) Methods of soil analysis-Physical and mineralogical properties, including statistics of measurement and sampling. Agronomy Series 9. American Society of Agronomy, Madison, p. 499-510, 1965. https://doi.org/10.2134/agronmonogr9.1.c39

KRAVCHENKO, A.; ZHANG, R. D. Estimating the soil water retention from particle-size distribution: a fractal approach. Journal Soil Science, Estados Unidos, v. 163, n. 3, p. 171-179, 1998. http:/doi.org/10.1097/00010694-199803000-00001

LIAO, K.; LAI, X.; ZHOU, Z.; ZHU, Q. Applying fractal analysis to detect spatio-temporal variability of soil moisture content on two contrasting land use hillslopes. Catena, Alemanha, v. 157, p. 163-172, 2017. http://doi.org/10.1016/j.catena.2017.05.022

LIU, X.; ZHANG, G.; HEATHMAN, G. C.; WANG, Y.; HUANG, C. H. Fractal features of soil particle-size distribution as affected by plant communities in the forested region of Mountain Yimeng, China. Geoderma, Amsterdã, v. 154, n. 1, p. 123-130, 2009. http://doi.org/10.1016/j.geoderma.2009.10.005

MANDELBORT, B. B. The Fractal Geometry of Nature. WH Freeman, San Francisco, p. 45-256, 1982.

MANTOVANELli, B. C.; SILVA, D. A. P.; CAMPOS, M. C. C.; GOMES, R. P.; SOARES, M. D. R.; SANTOS, L. A. C. Avaliação dos atributos do solo sob diferentes usos na região de Humaitá, Amazonas. Revista de Ciências Agrárias, Belém, v. 58, n. 2, p. 122-130, 2015. http://dx.doi.org/10.4322/rca.1822

MOTA JÚNIOR, P. C.; CAMPOS, M. C. C.; MANTOVANELLI, B. C.; FRANCISCON, U.; CUNHA, J. M. Variabilidade espacial de atributos físicos do solo em terra preta de índio sob cultivo de café Conilon. Cooffe Science, Viçosa, v. 12, n. 2, p. 260-271, 2017. https://doi.org/10.25186/cs.v12i2.1277

R CORE TEAM. A language and environment for statistical computing. Vienna, Austria: R Foundation for Statistical Computing, 2013. Available in: <https://www.r-project.org/>.

SILVA, F. A. S.; AZEVEDO, C. A. V. The Assistat Software Version 7.7 and its use in the analysis of experimental data. African Journal of Agricultural Research, Lagos, v. 11, n. 39, p. 3733-3740, 2016. http://doi.org/10.5897/AJAR2016.11522

SILVA, L. F. D.; CUNHA, J. M.; CAMPOS, M. C. C.; LIMA, A. F. L.; PANTOJA, J. C. M.; SOARES, M. D. R.; MANTOVANELLI, B. C. Variabilidade espacial de agregados e estoque de carbono em solos antropogênicos sob floresta nativa. Nativa, Sinop, v. 5, (especial), p. 540-547, 2017. http://dx.doi.org/10.5935/2318-7670.v05nespa12

SOARES, M. D. R.; CAMPOS, M. C. C.; CUNHA, J. M.; MANTOVANELLI, B. C.; OLIVEIRA, I. A.; BRITO FILHO, E. G.; LEITE, A. F. L. Variabilidade espacial da estabilidade dos agregados e matéria orgânica do solo em terra preta arqueológica sob pastagem. Gaia Scientia, Recife, v. 12, n. 1, p. 125-133, 2018. http://doi.org/10.22478/ufpb.1981-1268.2018v12n2.34416

SOIL SURVEY STAFF. Keys to soil taxonomy. 12th ed. Washington, DC: United States Department of Agriculture, Natural Resources Conservation Service, 2014, 400 p. 
TORMENA, C. A.; BARBOSA, M. C.; COSTA, A. C. S.; GONÇALVES, A. C. A. Densidade, porosidade e resistência à penetração em Latossolo cultivado sob diferentes sistemas de preparo do solo. Scientia Agricola, Piracicaba, v. 59, n. 4, p. 795-801, 2002. http://dx.doi.org/10.1590/S0103-90162002000400026

TURCOTTE, D. L. Fractal fragmentation. Journal of Geophysical Research, v. 91, p. 1921-1926, 1986. https://doi.org/10.1029/JB091iB02p01921

TYLER, S. W.; WHEATCRAFT, S. W. Application of fractal mathematics to soil water retention estimation. Soil Science Society of America Journal, Madison, v. 53, n. 4, p. 987-996, 1989.

http://doi.org/10.2136/sssaj1989.03615995005300040001x

XIA, D.; DENG, Y.; WANG, S.; DING, S.; CAI, C. Fractal features of soil particle-size distribution of different weathering profiles of the collapsing gullies in the hilly granitic region, south China. Natural Hazards, Basingstoke, v. 79, n. 1, p. 455-478, 2015. https://doi.org/10.1007/s11069-015-1852-1

XU, G.; LI, Z.; LI, P. Fractal features of soil particle-size distribution and total soil nitrogen distribution in a typical watershed in the source area of the middle Dan River, China. Catena, Alemanha, v. 101, p. 17-23, 2013. https://doi.org/10.1016/j.catena.2012.09.013

ZONEAMENTO ECOLÓGICO ECONÔMICO - ZEE. Zoneamento Ecológico Econômico do Sul-Sudeste do Amazonas. Instituto de Proteção Ambiental da Amazônia (IPAAM), Manaus, 2008, 79 p. 